Edoardo Barbieri (Ed.), "Ad stellam." Il Libro d'Oltramare di Niccolò da Poggibonsie altri resoconti di pellegrinaggio in Terra Santa fra Medioevo ed Età moderna. Atti della giornata di studi. Milano, Biblioteca Nazionale Braidense, 5 dicembre 2017 [Studi sulle abbazie storiche e ordini religiosi della Toscana 2], Olschki, Firenze 2019, xxiv + 220 pp. ISBN 9788822266408 . $€ 25$.

The ten papers in this book, originally presented at a conference in Milan in 2017, have as their central subject the fourteenth-century Franciscan Niccolò da Poggibonsi who wrote one of the most popular accounts of the pilgrimage to Jerusalem, the Libro d'Oltramare. Written in the vernacular, it survives in numerous manuscripts. Marco Giola gives a list of nineteen existing ones and two lost ones. The majority are at the Biblioteca Nazionale Centrale in Florence, but other copies are to be found in Florence at the Biblioteca Riccardiana, in the Vatican, Jerusalem, Lonato del Garda, Milan, New York, Paris, and Siena, while the two lost ones are recorded as having been in Jerusalem and Perugia respectively. The work was first printed in an anonymous abridgement in Bologna in 1500 with the title Viazo da Venesia al Sancto Iherusalem (studied here by Edoardo Barbieri). We see from Alessandro Tedesco's article that it became immensely successful after a second edition had been published in Venice by Niccolò d'Aristotele de' Rossi, known as Zoppino, in 1518. By 1800 it had gone through some 70 issues. Many of these had more or less elaborate illustrations by a variety of artists (but not, it would seem, by Niccolò himself), and it was what Kathryn Blair Moore calls in her foreword Niccolò's "pictorial sensibility" that made his work so attractive. For Niccolò urged his readers to absorb the features of every pilgrimage site and compared the churches he had visited in the Levant to the far more accessible ones in Italy.

A number of the papers in this collection dwell on the appeal to the reader's imagination made by the various accounts of the pilgrimage. This, in its turn, led to the creation in Italy in the late fifteenth century of the so-called Sacri Monti, sacred areas, close to home and intended as a substitute for places on the way to the Holy Sepulchre (discussed by Guido Gentile). It also led to an attempt to transform Italian cities familiar to the reader into areas of pilgrimage themselves. One of the most interesting cases, studied by Cristina Acidini, is that of the Florentine goldsmith Marco di Bartolomeo Rustici who, in 14411442, performed a pilgrimage, passing from one church to another, within the city of Florence. In Rustici's imagination Florence had turned into Jerusalem and his manuscript account, Dimostrazione dell'andata o viaggio al Santo Sepolcro e al Monte Sinai, not only gives extraordinarily detailed descriptions of the monuments he visited but also contains remarkable illustrations, including drawings of the Baptistery, the Duomo, the church of San Lorenzo, and the ora- 
tory of Santa Maria della Tromba which are well reproduced at the end of the article. The drawings are exceptionally accurate and are an invaluable record of the appearance of the Florentine monuments at the time.

Various other accounts of the pilgrimage are also discussed in "Ad stellam." Marzia Caria deals with the Tratatello delle indulgentie de Terra Sancta by the Franciscan missionary Francesco Suriano from Venice who spent many years in the Levant and acted twice, in 1493 and 1513, as the custodian of Mount Sion and the Holy Sepulchre. The work contains a number of different texts giving information about Jerusalem and, in keeping with the tradition of Niccolò da Poggibonsi, making comparisons between the Holy Land and Umbria. Michele Campopiano examines the Itinerarium of the German Franciscan Paul Walter von Guglingen who left his convent in Heidelberg in 1481 and reached the Holy Land in the following year after an extended visit to Italy which, together with his reasons for undertaking the pilgrimage, he describes in detail in his report. A later account of the pilgrimage performed by Marco Lusardi in 1588, the Viaggio devotissimo di Gerusalemme, is studied by Gabriele Nori.

"Ad stellam" ends with Luca Rivali's survey of nineteenth- and twentiethcentury bibliographical repertories of accounts of the pilgrimage to Jerusalem. Despite what seems to have been a diminished interest in pilgrims in the first part of the twentieth century, the repertories are numerous. Rivali discusses some of the early ones about Franciscans and by Franciscans, the first published in 1879 by Marcellino da Civezza, and the second, which finally appeared in 1906 and is of the utmost value to this day, by Girolamo Golubovich. Ludovic Lalanne in France published his book on pilgrims before the Crusades in 1845, and the Swiss doctor Tobias Tobler produced more general studies which included his Bibliographia geographica Palaestinae of 1867 and influenced the important work of Reinhold Röhricht. If Röhricht concentrated on German pilgrims in publications produced between 1874 and 1885 Pietro Amat di San Filippo dealt with the Italians, while the repertory by Agustín Arce, which appeared in 1947, was of pilgrimage accounts by Spaniards. Other more recent surveys have been published by contributors to the present volumeAlessandro Tedesco and Rivali himself. Over the centuries pilgrimage in general has emerged as a subject of enduring fascination. The meticulous studies edited by Edoardo Barbieri in "Ad stellam" will interest art historians, bibliographers, and codicologists as well as supplying the less specialised reader with welcome information.

\section{Alastair Hamilton}

The Warburg Institute, London

alastair.hamilton@sas.ac.uk 